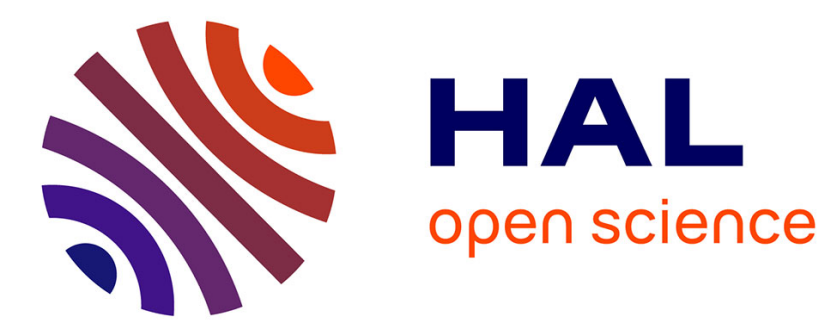

\title{
Scalable asymmetric synthesis of a key fragment of Bcl-2/Bcl-xL inhibitors $\dagger$
}

Sylvain Laclef, Catherine Taillier, Christine Penloup, Aurélie Viger, Jean-François Brière, Christophe Hardouin, Vincent Levacher

\section{- To cite this version:}

Sylvain Laclef, Catherine Taillier, Christine Penloup, Aurélie Viger, Jean-François Brière, et al.. Scalable asymmetric synthesis of a key fragment of Bcl-2/Bcl-xL inhibitors $\dagger$. RSC Advances, 2014, 4 (75), pp.39817-39821. 10.1039/c4ra07821g . hal-01141445

\section{HAL Id: hal-01141445 \\ https://hal.science/hal-01141445}

Submitted on 13 Apr 2015

HAL is a multi-disciplinary open access archive for the deposit and dissemination of scientific research documents, whether they are published or not. The documents may come from teaching and research institutions in France or abroad, or from public or private research centers.
L'archive ouverte pluridisciplinaire HAL, est destinée au dépôt et à la diffusion de documents scientifiques de niveau recherche, publiés ou non, émanant des établissements d'enseignement et de recherche français ou étrangers, des laboratoires publics ou privés. 
(2rossMark

Cite this: RSC Adv., 2014, 4, 39817

Received 20th May 2014

Accepted 7th August 2014

DOI: $10.1039 / c 4 r a 07821 g$

www.rsc.org/advances

The asymmetric synthesis of a 1,3-diamine building block for the elaboration of $\mathrm{Bcl}-2$ and $\mathrm{Bcl}-{ }_{\mathrm{xL}}$ protein inhibitors is described through two key steps: (1) a highly diastereoselective aza-Reformatsky reaction, and (2) a chemoselective amination under Mitsunobu conditions. This synthetic sequence was also demonstrated to be successfully amenable to a large-scale synthesis.

Defects in the apoptotic processes ${ }^{1}$ play an important role in tumour initiation, progression and chemoresistance. ${ }^{2}$ Among the apoptosis regulator Bcl-2 family (B-cell lymphoma 2), the anti-apoptotic Bcl-2 and $\mathrm{Bcl}^{-}{ }_{\mathrm{xL}}$ proteins were found to be overexpressed in many cancers..$^{3-5}$ As part of a complex orchestration to regulate cell fate, the anti-apoptotic Bcl-2 and $\mathrm{Bcl}_{-\mathrm{xL}}$ proteins and others inhibit pro-apoptotic proteins such as BAK and BAX. Importantly, these interactions can be antagonised by BH3-only proteins (BAD, BIM and NOXA) possessing a single BH domain and displaying a large hydrophobic groove with the same fold. Consequently, the development of small molecule BH3 mimetics as inhibitors of anti-apoptotic $\mathrm{Bcl}-2$ and $\mathrm{Bcl}_{\mathrm{xL}}$ proteins is attractive for novel anticancer therapy. ${ }^{6-9}$

A fragment-based drug design ${ }^{10}$ approach has led to the discovery of several ${ }^{11}$ potent Bcl-2 and Bcl- ${ }_{\mathrm{xL}}$ inhibitors such as $\mathbf{1}$ in Abbott Laboratories (ABT-737, Fig. 1). ${ }^{12}$ Analogues based on similar scaffolds were recently developed. ${ }^{13}$ In that field of research (Fig. 1), Servier Laboratories developed conformationally restricted isosters 2 , which displayed submicromolar activity. The tricyclic architecture was aimed at addressing both the solubility issues and at modulating the interactions with the hydrophobic groove of the proteins. Extensive structure-activity

${ }^{a}$ Normandie UNIV, COBRA, UMR 6014 et FR3038; Univ Rouen; INSA Rouen; CNRS, IRCOF, 1 rue Tesnière, 76821 Mont Saint Aignan Cedex, France. E-mail: vincent. levacher@insa-rouen.fr

${ }^{b}$ Oril Industrie, 13 rue Auguste Desgenétais, 76210 Bolbec, France. E-mail: christophe. hardouin@fr.netgrs.com

$\dagger$ Electronic supplementary information (ESI) available: For procedures and compound characterisation. See DOI: 10.1039/c4ra07821g

$\$$ These two researchers equally contributed to this project. relationship studies revealed the essential importance of common diamine fragments such as $3,{ }^{14}$ containing a $1,3-$ diamine moiety flanked by a phenylthioethyl arm, for securing both bioavailability and the potent inhibition of Bcl antiapoptotic proteins. These outcomes highlighted that the $R$ isomer displayed better bioactivity than the opposite enantiomer.

As far as the construction of diamine fragment 3 was concerned, only one chiral pool based synthesis was reported using L-aspartic acid precursor. ${ }^{15}$ This method allowed the synthesis of compound 3 in eight steps and with a $30 \%$ overall yield.

In this context, we endeavoured to develop a reliable access toward diamine 3 through an alternative asymmetric synthesis approach. The aim is eventually to achieve a flexible larger-scale synthetic sequence, en route to providing significant amounts of Bcl-2 protein inhibitor from the key building block 3 . The retrosynthetic approach is based on both diastereoselective

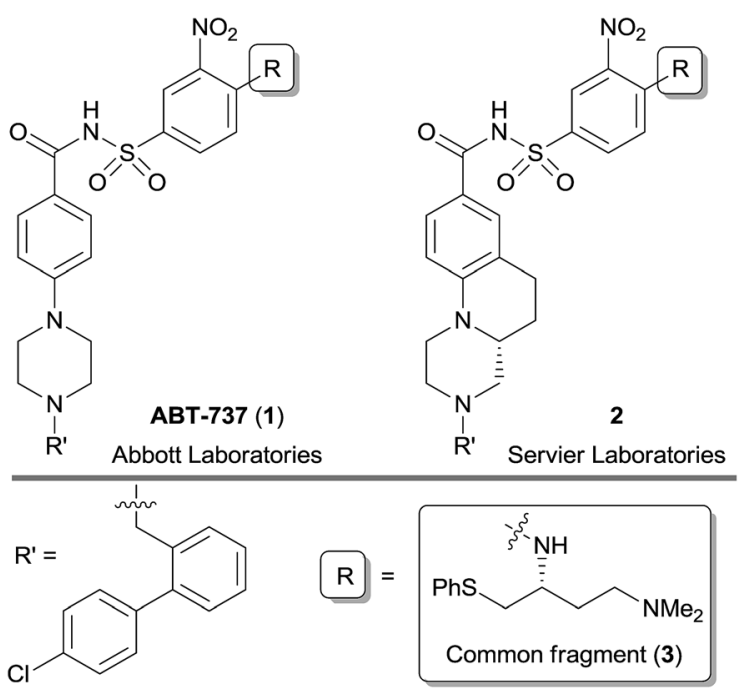

Fig. 1 Structures of $\mathrm{Bcl}-2 / \mathrm{BCl}_{-\mathrm{xL}}$ inhibitors. 
aza-Reformatsky (6 to 5) and chemoselective amination key reactions (4 to 3, Scheme 1 ). First, chiral Ellman's $N$-tert-butanesulfinamide, readily available on a large scale as both enantiomers, was selected as a versatile chiral auxiliary for the asymmetric synthesis of amine 5. ${ }^{\mathbf{1 6}}$ However, despite previous examples reporting the use of chiral Ellman's sulfinimines in Reformatsky reactions, ${ }^{17}$ the influence of the thioether functionality of 6 on both reactivity and diastereoselectivity remains an open issue. Then, we sought to capitalize on the $N$-sulfinyl protecting group of $\mathbf{5}$, in order to perform further functional group manipulation, like the key chemoselective amination step on 4. We are pleased to report herein our efforts towards the development of a scalable diastereoselective synthesis of chiral scaffold $\mathbf{3}$, a potentially versatile and useful building block in medicinal chemistry.

According to literature procedures, bromoacetaldehyde acetal 7 was converted to the aldehyde precursor 8 in two steps (Scheme 2). ${ }^{18}$ The transformation of the rather unstable aldehyde 8 into the corresponding enantiomerically pure $\mathrm{N}$-(tertbutylsulfinyl)imine $\mathbf{6}$ was successfully carried out with copper(II) sulfate as the dehydrating agent in a $70 \%$ yield. ${ }^{16}$ These conditions were superior to the standard use of $\mathrm{Ti}(\mathrm{OEt})_{4}$, which gave 6 in only a $52 \%$ yield. It should be noted that other chiral auxiliaries, such as $(R)$-1-phenylethylamine or $(R)$-2-methoxy-1phenylethylamine, failed to give the corresponding imines, highlighting the robustness of the Ellman's sulfinamides approach.

Then, the sulfinimine $\mathbf{6}$ was treated with an excess of the Reformatsky reagent derived from the corresponding bromo acetate 10 (2.2 equiv.) under Barbier's conditions (Scheme 3). ${ }^{19}$ Pleasingly, the desired product 5 was obtained in a $85 \%$ yield, with a high diastereoisomeric ratio (d.r. > $95: 5$ ). Actually, changing the reaction temperature from $50{ }^{\circ} \mathrm{C}$ to $0{ }^{\circ} \mathrm{C}$ had negligible impact on d.r., although it led to lower yields in some cases. By means of Red-Al, the methyl ester 5 was easily reduced, to furnish the desired $(R)$-alcohol 4 in a $70 \%$ yield. Based on Ellman's model, already applied to the Reformatsky reagent originating from 10, we propose the following explanation to account for the diastereoinduction outcome. ${ }^{16,17 c}$ Considering that the Reformatsky reagent derived from methyl bromoacetate 10 exists as a monomeric C-metallated species in polar solvents, ${ }^{20}$ a regular Zimmerman-Traxler transition state involving a six-membered intermediate with zinc metals coordinated to the sulfinyl oxygen is proposed. Then, the nucleophilic attack of the Reformatsky reagent to the $R e$ face of imine takes place (Scheme 3). The high diastereoselectivity obtained demonstrates that the putative coordination between sulfinimine and zinc is not disturbed by other complexing functions such as the thioether moiety.

Two different pathways were next considered to transform the primary alcohol $\mathbf{4}$ into the tertiary amine $\mathbf{1 1}$ (Scheme 4). First, following a two-step sequence, the alcohol 4 was converted quantitatively to aldehyde 12 using the mild 2,2,6,6-tetramethyl-1-piperidinyloxyl and [bis(acetoxy)-iodo]benzene (TEMPO-BAIB) oxidative system (Route A, Scheme 4). ${ }^{21}$ Then, the crude aldehyde 12 underwent a reductive amination sequence in the presence of $\mathrm{NaBH}(\mathrm{OAc})_{3}$ to give amine $\mathbf{1 1}$ in a

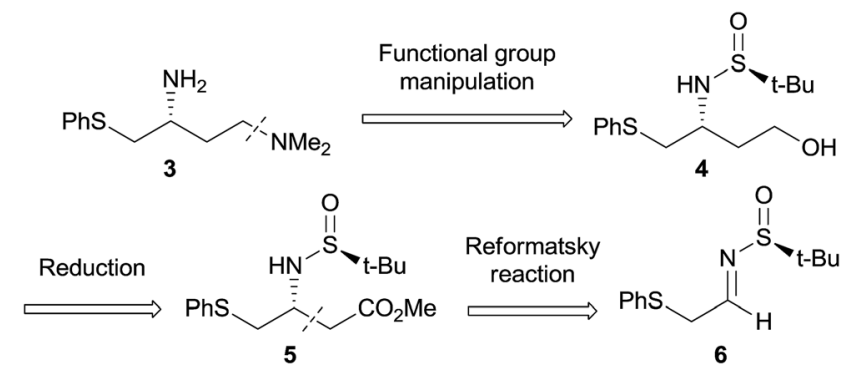

Scheme 1 Asymmetric synthesis approach of diamine fragment.

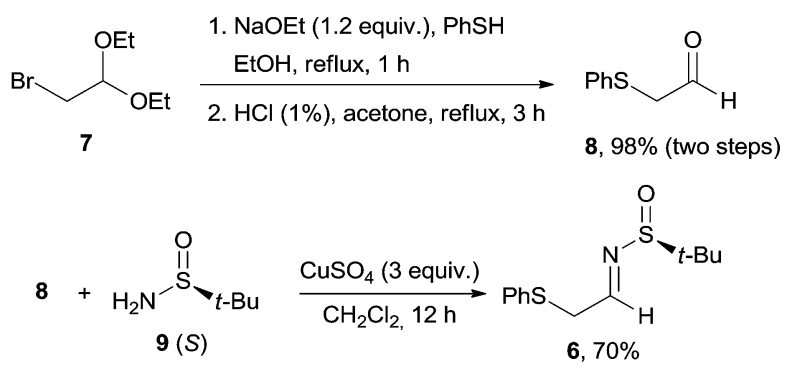

Scheme 2 Synthesis of sulfinimine intermediate 6 .

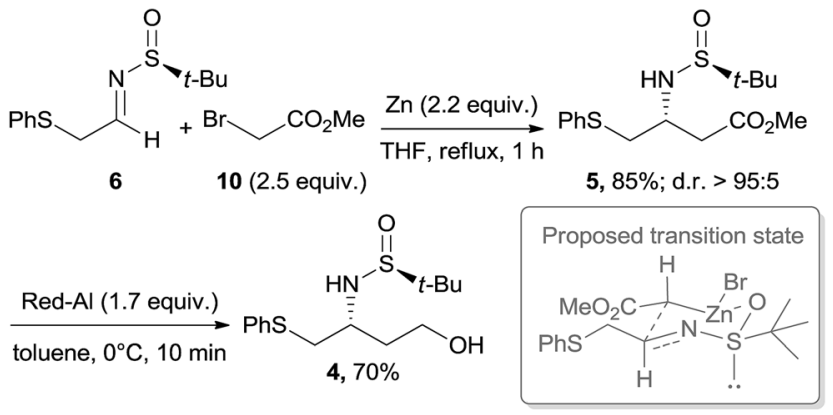

Scheme 3 The key Reformatsky reaction.

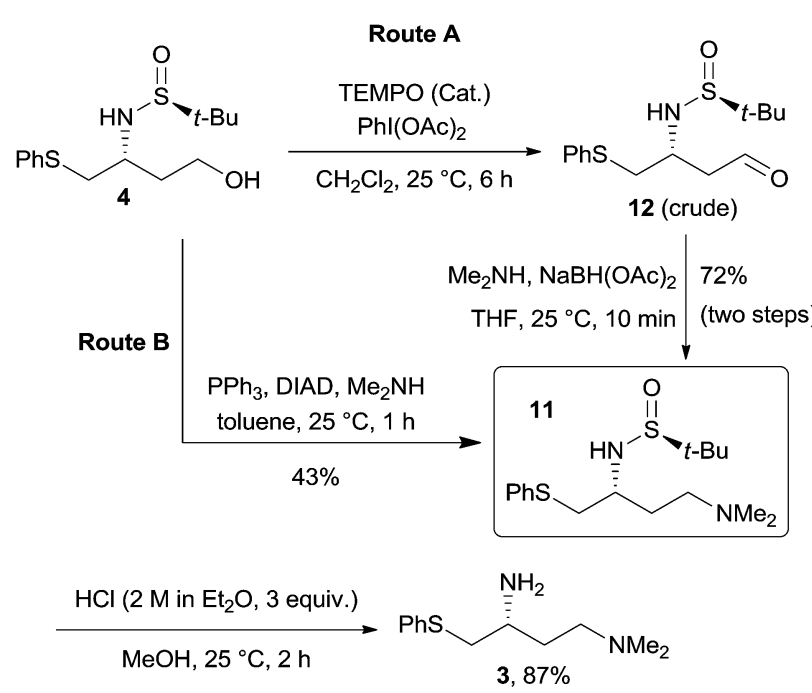

Scheme 4 Completion of the synthesis of diamine fragment 3. 
(a) Intramolecular Mitsunobu amination step<smiles>[R]C(NS(=O)CCC)C(=O)N1CCCC1[R]</smiles>

(b) Intermolecular Mitsunobu amination step

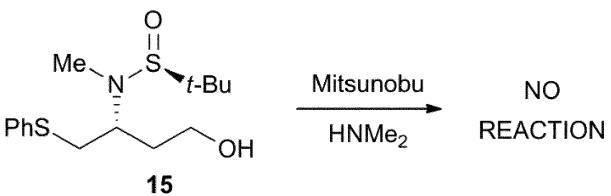

Scheme 5 Inter-versus intra-molecular amination under Mitsunobu conditions.

$72 \%$ overall yield. Unfortunately, we encountered significant reproducibility issues due to the instability of aldehyde $\mathbf{1 2}$ when attempting to scale up the reaction. To overcome these difficulties, an alternative approach (Route B) based on a one-step Mitsunobu reaction with dimethylamine was studied. ${ }^{22}$ This strategy led to the formation of product 11, with a respectable yield of $43 \%$ and, more importantly, with a robust scalable protocol (vide infra). Finally, the deprotection of the $N$-sulfinyl functional group of $\mathbf{1 1}$ was achieved under regular acidic conditions, affording the target diamine molecule 3 in a $87 \%$ yield. The $R$-absolute configuration was assigned at that stage by comparison with the optical rotation previously reported. ${ }^{\mathbf{1 0}}$
It is worth pointing out that the outcome of the Mitsunobu reaction (Route $\mathrm{B}$, Scheme 4 ) is surprising considering the low acidity of both the primary alcohol $\mathbf{4}$ and dimethylamine starting materials, especially in the presence of the NHSOt-Bu moiety. Indeed, it was reported in the literature that tert-butylsulfinamines 13 can react intramolecularly with a proximate alcohol to form a five-membered pyrrolidine ring 14 (Scheme 5a). ${ }^{23}$ In our case, the formation of a four-membered azetidine ring should be more energetically demanding. ${ }^{24}$ Moreover, we could demonstrate (see supporting information $\dagger$ ) that the $\mathrm{N}$-methylated precursor $\mathbf{1 5}$ did not react under the Mitsunobu conditions with dimethylamine (Scheme 5b). Therefore, we assume that the $\mathrm{NH}$ bond favours the formation of the phosphonium intermediate, thereby allowing the subsequent nucleophilic substitution to take place, even with dimethylamine having a high $\mathrm{p} K_{\mathrm{a}}$ value. On the other hand, the formation of a phosphorane intermediate could not be ruled out. ${ }^{25}$

Next, we embarked on a larger scale synthesis of diamine target 3 by optimizing our validated sequence, with special attention paid to minimize the number of purification procedures initially required at each reaction step (Scheme 6). Subsequent to the easy formation of sulphide $\mathbf{1 6}$ on a 2 kilogram scale, the acetal deprotection into aldehyde 8 was performed with $\mathrm{H}_{2} \mathrm{SO}_{4}$, in order to prevent the use of corrosive $\mathrm{HCl}$. Keeping the green solvent MeTHF as the reaction media, the formation of imine $\mathbf{6}$ was conveniently carried out by means of a Dean-Stark distillation in the presence of the soft PPTS acid. This allowed the formation of sulfinimide 6 in a $68 \%$ crude yield (see supporting information $\dagger$ ) on a kilogram scale through three telescoped steps (7 to 6). Though the purity of the product

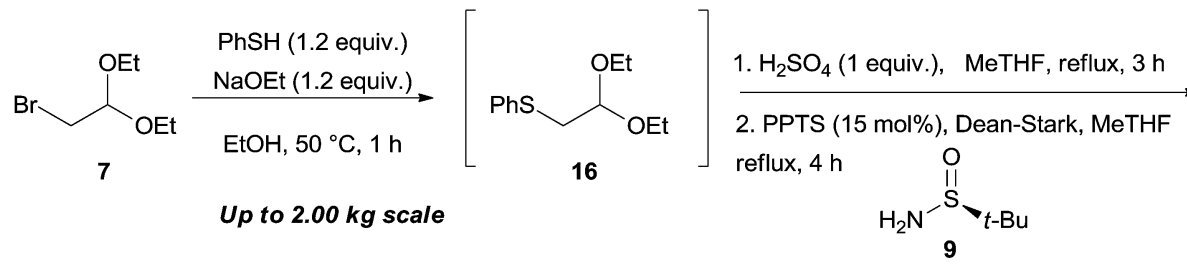

$\mathrm{Zn}$ (3.0 equiv.), DIBAL-H ( 0.1 equiv.) methyl bromoacetate ( 1.6 equiv.)

THF, $20^{\circ} \mathrm{C}, 30 \mathrm{~min}$

Up to $30 \mathrm{~g}$ scale

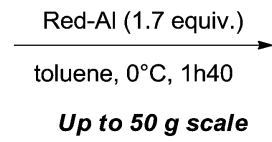

Up to $50 \mathrm{~g}$ scale

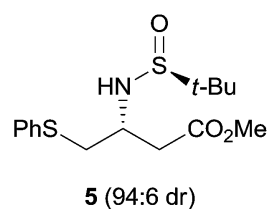

$80 \%$ crude yield, $68 \%$ HPLC purity $82 \%$ HPLC purity after column
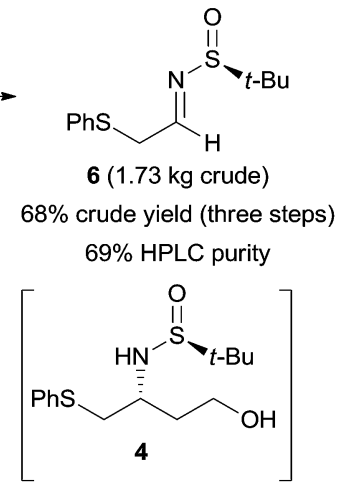

$80 \%$ Crude yield $89 \%$ HPLC purity

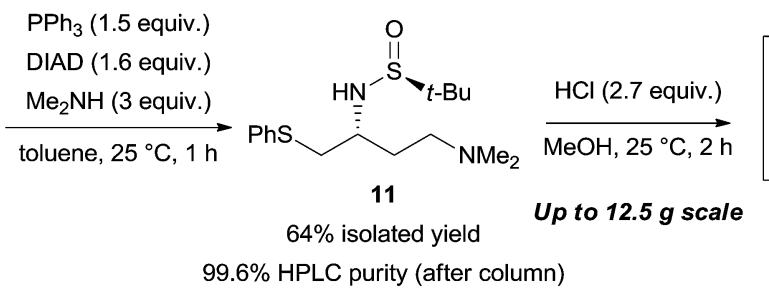

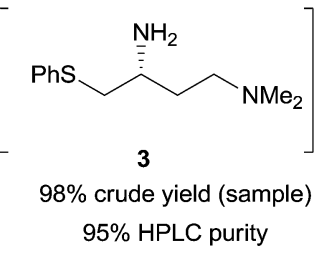

fumaric acid

(1.8 equiv.)

$\mathrm{MeOH}$, reflux

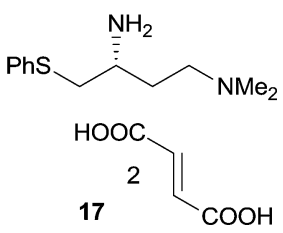

$80 \%$, HPLC purity $>99 \%$

$99.5 \%$ ee

Scheme 6 Scale-up synthesis of diamine building block 3 fumarate salt. 
was estimated to be only $69 \%$ by means of HPLC analysis, this quality turned out to be sufficient for the subsequent steps. Disappointingly, a solvent screening revealed that the next Reformatsky reaction led to partial conversions in MeTHF solvent. Further optimisation and switching to THF demonstrated that imine $\mathbf{6}$ was completely transformed into amine $\mathbf{5}$ with a high diastereoisomeric ratio of $94: 6$, after a soft citric acid work-up to preserve the chiral auxiliary. It is worth noting that, according to a literature procedure, ${ }^{17 \boldsymbol{d}}$ the activation of zinc metal by DIBAL-H is preferred to avoid the initially uncontrollable exothermicity during the Reformatsky's reagent formation. A column chromatography on silica gel improved the purity of product 5 from $68 \%$ to $82 \%$, as estimated by HPLC analysis, which was found to be sufficient for the next step. The reduction of the ester group by Red-Al (5 to 4 ) and the subsequent Mitsunobu reaction were next successfully telescoped in the same solvent to furnish the crude amine 11. A silica gel column chromatography was required to remove the large amount of triphenylphosphine side product, and to allow the isolation of amine $\mathbf{1 1}$ in a good 64\% yield and more than 99\% purity, as measured by HPLC. Moreover, the isolation of the pure major diastereoisomer of $\mathbf{1 1}$ was secured at this stage. The chiral auxiliary was removed by $\mathrm{HCl}$ in methanol, and the corresponding diamine 3 was obtained in toluene solution after neutralization. Then, the final product $\mathbf{1 7}$ was conveniently isolated as a solid fumarate salt which furnished a pure material in $99.5 \%$ ee. It is worth noting that all attempts to perform the one-step deprotection of sulfinamine $\mathbf{1 1}$ by fumaric acid were unsuccessful.

\section{Conclusions}

A novel asymmetric synthesis of an enantiopure 1,3-diamine 3, a key fragment of potent $\mathrm{Bcl}-2 / \mathrm{Bcl}^{-}{ }_{\mathrm{xL}}$ protein inhibitor, was accomplished in seven linear steps. The two key steps involve both a highly diastereoselective aza-Reformatsky reaction on a chiral sulfinimine and a chemoselective Mitsunobu reaction allowing the introduction of the dimethylamine moiety. This laboratory synthesis of diamine $\mathbf{3}$ was demonstrated to be amenable to a larger-scale process up to the kilogram scale for some steps and required only two purifications by column chromatography. Both enantiomers of diamine 3 were shown to be available as useful building blocks of bioactive material.

\section{Acknowledgements}

This work has been partially supported by INSA Rouen, Rouen University, CNRS, EFRD, Labex SynOrg (ANR-11-LABX-0029) and Région Haute-Normandie (CRUNCH network). We warmly thank J.-P. Lecouvé, the pilot plant team and the analytical team for their valuable support.

\section{Notes and references}

1 (a) N. N. Danial and S. J. Korsmeyer, Cell, 2004, 116, 205; (b) J. C. Reed, Am. J. Pathol., 2000, 157, 1415; (c) D. L. Vaux and S. J. Korsmeyer, Cell, 1999, 96, 245.
2 (a) E. R. McDonald III and W. S. El-Deiry, Death Recept. Cancer Ther., 2005, 1; (b) D. W. Nicholson, Nature, 2000, 407, 810; (c) S. W. Lowe and A. W. Lin, Carcinogenesis, 2000, 21, 485; (d) B. A. Ponder, Nature, 2001, 411, 336.

3 (a) J. M. Adams and S. Cory, Science, 1998, 281, 1322; (b) A. Gross, J. M. McDonnell and S. J. Korsmeyer, Genes Dev., 1999, 13, 1899.

4 (a) V. Kitrkin, S. Joos and M. Zornig, Biochim. Biophys. Acta, 2004, 1644, 229; (b) S. Cory and J. M. Adams, Nat. Rev. Cancer, 2002, 2, 647; (c) D. Hanahan and R. A. Weinberg, Cell, 2000, 100, 57.

5 (a) J. C. Reed, Adv. Pharmacol., 1997, 41, 501; (b) J. M. Adams and S. Cory, Oncogene, 2007, 26, 1324.

6 (a) J. M. Adams and S. Cory, Oncogene, 2007, 26, 1324; (b) P. Juin, O. Geneste, E. Raimbaud and J. A. Hickman, Biochim. Biophys. Acta, 2004, 1644, 251.

7 A. M. Petros, E. T. Olejniczak and S. W. Fesik, Biochim. Biophys. Acta, 2004, 1644, 83.

8 M. Sattler, H. Liang, D. Nettesheim, R. P. Meadows, J. E. Harlan, M. Eberstadt, H. S. Yoon, S. B. Shuker, B. S. Chang, A. J. Minn, C. B. Thompson and S. W. Fesik, Science, 1997, 275, 983.

9 (a) Y. Feng, X. Ding, T. Chen, L. Chen, F. Liu, X. Jia, X. Luo, X. Chen, K. Chen, H. Jiang, H. Wang, H. Liu and D. Liu, J. Med. Chem., 2010, 53, 3465; (b) J. Wei, S. Kitada, M. F. Rega, J. L. Stebbins, D. Zhai, J. Cellitti, H. Yuan, A. Emdadi, R. Dahl, Z. Zhang, L. Yang, J. C. Reed and M. Pellecchia, J. Med. Chem., 2009, 52, 4511; (c) G. Lessene, P. E. Czabotar and P. M. Colman, Nat. Rev. Drug Discovery, 2008, 7, 989; (d) G. Tang, Z. Nikolovska-Coleska, S. Qiu, C.-Y. Yang, J. Guo and S. Wang, J. Med. Chem., 2008, 51, 717; (e) G. Tang, C.-Y. Yang, Z. Nikolovska-Coleska, J. Guo, S. Quiu, R. Wang, W. Gao, G. Wang, J. Stuckey, K. Krajewski, S. Jiang, P. P. Roller and S. Wang, J. Med. Chem., 2007, 50, 1723; (f) A. M. Petros, J. Dinges, D. J. Augeri, S. A. Baumeister, D. A. Betebenner, M. G. Bures, S. W. Elmore, P. J. Hajduk, M. K. Joseph, S. K. Landis, D. G. Nettesheim, S. H. Rosenberg, W. Shen, S. Thomas, X. Wang, I. Zanze, H. Zhang and S. W. Fesik, J. Med. Chem., 2006, 49, 656.

10 T. Oltersdorf, S. W. Elmore, A. R. Shoemaker, R. C. Armstrong, D. J. Augeri, B. A. Belli, M. Bruncko, T. L. Deckwerth, J. Dinges, P. J. Hajduk, M. K. Joseph, S. Kitada, S. J. Korsmeyer, A. R. Kunzer, A. Letai, C. Li, M. J. Mitten, D. G. Nettesheim, S. Ng, P. M. Nimmer, J. M. O'Connor, A. Oleksijew, A. M. Petros, J. C. Reed, W. Shen, S. K. Tahir, C. B. Thompson, K. J. Tomaselli, B. Wang, M. D. Wendt, H. Zhang, S. W. Fesik and S. H. Rosenberg, Nature, 2005, 435, 677.

11 (a) S. Barelier, J. Pons, O. Marcillat, J.-M. Lancelin and I. Krimm, J. Med. Chem., 2010, 53, 2577; (b) P. J. Hajduk and J. A. Greer, Nat. Rev. Drug Discovery, 2007, 6, 211.

12 C.-M. Park, M. Bruncko, J. Adickes, J. Bauch, H. Ding, A. Kunzer, K.-C. Marsh, P. Nimmer, A. R. Shoemaker, X. Song, S. K. Tahir, C. Tse, X. Wang, M. D. Wendt, X. Yang, H. Zhang, S. W. Fesik, S. H. Rosenberg and S. W. Elmore, J. Med. Chem., 2008, 51, 6902. 
13 (a) Y. Tanaka, K. Aikawa, G. Nishida, M. Homma, S. Sogabe, S. Igaki, Y. Hayano, T. Sameshima, I. Miyahisa, T. Kawamoto, M. Tawada, Y. Imai, M. Inazuka, N. Cho, Y. Imaeda and T. Ishikawa, J. Med. Chem., 2013, 56, 9635;

(b) H. Zhou, A. Aguilar, J. Chen, L. Bai, L. Liu, J. L. Meagher, C.-Y. Yang, D. McEachern, X. Cong, J. A. Stuckey and S. Wang, J. Med. Chem., 2012, 55, 6149; (c) G. Lessene, P. E. Czabotar and P. M. Colman, Nat. Rev. Drug Discovery, 2008, 7, 989.

14 (a) M. Bruncko, T. K. Oost, B. A. Belli, H. Ding, M. K. Joseph, A. Kunzer, D. Martineau, W. J. McClellan, M. Mitten, S.-C. Ng, P. M. Nimmer, T. Oltersdorf, C.-M. Park, A. M. Petros, A. R. Shoemaker, X. Song, X. Wang, M. D. Wendt, H. Zhang, S. W. Fesik, S. H. Rosenberg and S. W. Elmore, J. Med. Chem., 2007, 50, 641; (b) M. D. Wendt, W. Shen, A. Kunzer, W. J. McClellan, M. Bruncko, T. K. Oost, H. Ding, M. K. Joseph, H. Zhang, P. M. Nimmer, S.-C. Ng, A. R. Shoemaker, A. M. Petros, A. Oleksijew, K. Marsh, J. Bauch, T. Oltersdorf, B. A. Belli, D. Martineau, S. W. Fesik, S. H. Rosenberg and S. W. Elmore, J. Med. Chem., 2006, 49, 1165.

15 (a) R. B. Biebold, T. Gero, P. Grover, S. Huang, S. Ioannidis, C. A. Ogoe, J. C. Saeh and J. G. Varnes, PCT Int. Appl., WO 2012017251, 2012; (b) O. J. Shah, Y. Shen, X. Lin, M. Anderson, X. Huang, J. Li and L. Li, PCT Int. Appl., WO 2011068863, 2011; (c) A. R. Kunzer, S. W. Elmore, L. Hexamer, C.-M. Park, A. J. Souers, G. M. Sullivan, G. T. Wang, X. Wang and M. D. Wendt, PCT Int. Appl., WO 2010083442, 2010; (d) S. W. Elmore, M. Bruncko and C.-M. Park, U.S. Pat. Appl. Publ., US 20050272744, 2005.

16 For a recent insightful review, see: M. T. Robak, M. A. Herbage and J. A. Ellman, Chem. Rev., 2010, 110, 3600. 17 (a) F. Grellepois, J. Org. Chem., 2013, 78, 1127; (b)

A. Sorochinsky, N. Voloshin, A. Markovsky, M. Belik, N. Yasuda, H. Uekusa, T. Ono, D. O. Berbasov and V. A. Soloshonok, J. Org. Chem., 2003, 68, 7448; (c)
D. D. Staas, K. L. Savage, C. F. Homnick, N. N. Tsou and R. G. Ball, J. Org. Chem., 2002, 67, 8276; (d) M. J. Girgis, J. K. Liang, Z. Du, J. Slade and K. Prasad, Org. Process Res. Dev., 2009, 13, 1094.

18 (a) H. Peng, Y. Cheng, N. Ni, M. Li, G. Choudhary, H. T. Chou, C.-D. Lu, P. C. Tai and B. Wang, ChemMedChem, 2009, 4, 1457; (b) H. Ishibashi, C. Kameoky, H. Iriyama, K. Kodama, T. Sato and M. Ikeda, J. Org. Chem., 1995, 60, 1276.

19 T. Scherkenbeck and K. Siegel, Org. Process Res. Dev., 2005, 9, 216.

20 J. Dekker, P. H. M. Budzelaar, J. Boersma and G. J. M. van des Kerk, Organometallics, 1984, 3, 1403.

21 A. De Mico, R. Margarita, L. Parlanti, A. Vescovi and G. Piancatelli, J. Org. Chem., 1997, 62, 6974.

22 The more classical two-step approach, namely the $N$ alkylation of dimethylamine by means of mesylated or tosylated alcohol 4 was also abandoned because of eratic outcomes obtained during the scale-up process mainly due to the poor stability of these labile sulfonate ester intermediates.

23 (a) I. Bosque, E. Bagdatli, F. Foubelo and J. C. GonzalezGomez, J. Org. Chem., 2014, 79, 1796; (b) K. N. Hahn, O. O. Fadeyi, H. P. Cho and C. W. Lindsley, Tetrahedron Lett., 2012, 53, 3577.

24 The Mitsunobu reaction conducted from the starting material 4 alone led after 1 hour to a complex mixture which failed to provide the desired product 11 upon subsequent addition of dimethylamine. This precludes the involvement of a four-membered ring azetine as a reactive intermediate. For the synthesis of stable $N$-tert-butylsulfinyl azetidines, see: C. Guérot, B. H. Tchitchanov, H. Knust and E. M. Carreira, Org. Lett., 2011, 13, 780.

25 I. Mathieu-Pelta and S. A. Evans Jr, J. Org. Chem., 1992, 57, 3409. 